\title{
To Be or Not To Be: Urban Refugees in Kampala
}

\author{
Jesse Bernstein and Moses Chrispus Okello
}

\section{Abstract}

In Uganda, refugee policy and programming is focused almost exclusively on providing protection and assistance to refugees residing in rural settlements. While international law allows refugees the right to freedom of movement and choice of residence, Ugandan legislation restricts refugees' residency to rural settlements, subjecting those who wish to live outside of settlements and in urban centres to severe restrictions. This study sheds light on the reasons refugees choose to reside in Kampala as opposed to rural settlements and the challenges they endure while attempting to sustain and support themselves. Research findings indicate that at all stages of exile, refugees in Uganda are put under pressure, either implicitly or explicitly, to relocate to settlements. The lack of progressive thinking and hence over-reliance on settlements as the mainstay of refugee protection and assistance has hampered reforms of refugee policy and hindered the broader involvement of municipal authorities in responding to protection and assistance needs of refugees in urban areas. Research findings suggest that many refugees have talents, skills, and abilities which would enable self-sufficiency in Kampala and other urban areas. However, these capabilities are currently undermined by a refugee regime which only promotes self-reliance in rural settlements. In an effort to enhance refugees' overall human security and to support their own efforts to become independent and self-reliant, this paper asserts that refugee policy in Uganda should be reformed to support refugees' decisions to choose their own places of residence, instead of restricting them to rural settlements.

\section{Résumé}

En Ouganda, la politique, ainsi que la programmation, à l'égard des réfugiés est centrée presque entièrement autour de la protection et l'assistance accordée aux réfugiés vivant dans les zones d'installations rurales. Bien que le droit international accorde aux réfugiés la liberté de mouvement et de choix de résidence, la législation Ougandaise restreint la résidence des réfugiés aux zones d'installations rurales, en imposant des restrictions sévères à ceux qui veulent vivre à l'extérieur des zones d'installations ou dans les centres urbains. Cette étude met en lumière les raisons pour lesquelles les réfugiés choisissent de vivre à Kampala, par opposition aux zones d'installations rurales, et les défis qu'ils subissent dans leur lutte pour se nourrir et subvenir à leurs propres besoins. Les recherches indiquent que pendant toute la durée de l'exil, les réfugiés en Ouganda subissent des pressions, implicites ou explicites, pour qu'ils s'établissent dans les zones d'installation. Le manque de raisonnement progressiste, d'où une trop grande dépendance sur les zones d'installations comme pilier pour fournir protection et assistance aux réfugies, a entravé les reformes dans la politique à l'égard des réfugies, et a empêché une implication plus poussée des autorités municipales pour répondre aux besoins de protection et d'assistance des réfugiés en milieu urbain. Les résultats des recherches donnent à penser que beaucoup de réfugiés possèdent des talents, des compétences et des aptitudes, qui pourraient leur permettre d'être autonomes à Kampala et dans d'autres zones urbaines. Cependant, ces aptitudes sont actuellement entravées par un régime de réfugié qui ne prône l'autonomie que dans les zones d'installations rurales. Dans un effort pour améliorer la sécurité humaine générale des réfugiés et pour soutenir leurs propres efforts pour devenir indépendants

(C) Jesse Bernstein and Moses Chrispus Okello, 2007. This open-access work is licensed under a Creative Commons Attribution-NonCommercial 4.0 International License, which permits use, reproduction and distribution in any medium for non-commercial purposes, provided the original author(s) are credited and the original publication in Refuge: Canada's Journal on Refugees is cited. 
et autonomes, cet exposé affirme que la politique à l'égard des réfugiés en Ouganda doit être réformée pour soutenir les décisions des réfugiés de choisir eux-mêmes leur lieu de résidence, au lieu de les restreindre aux zones d'installations rurales.

\section{Background}

$\mathrm{U}$ ganda is generally known for its "generosity" to refugees. This perceived benevolence is based on Uganda's long history of hosting refugees and the practice of parcelling out land to them, as a means of enhancing refugee protection and livelihoods, and an avenue through which refugees can regain a semblance of normalcy and in the short term be self-reliant as they await a durable solution. This very assertion is paradoxically premised on a legal framework that barely protects and only minimally enhances refugee livelihoods. This is because the assumptions underlying the self-perception of the Government of Uganda $(\mathrm{GoU})$ as generous to refugees and the international acclaim for Uganda's refugee policy and practice as generous are false: by preserving the settlement framework, policies and procedures governing refugee protection and assistance in Uganda, though seemingly cogent, remain, in fact, highly restrictive, ad hoc, and inconsistent ${ }^{1}$ with the protection needs of refugees and the long-term goals of the refugee self-reliance policy. Current policy and practice instead compels refugees to reside in rural resettlements. Moreover, since the refugee status determination (RSD) process conducted in Kampala is integral to the experiences of refugees, this paper, focusing on the plight of urban refugees in Kampala, also sheds light on persistent problems with the RSD process (many of which have previously been documented by the Refugee Law Project (RLP) ${ }^{2}$ and highlights a number of the ways in which the current assistance framework raises challenges to and dilutes the definition of the term "refugee."

Until May 2006, the Control of the Aliens Refugee Act (CARA), ${ }^{3}$ which required refugees to live in settlements and to only move out of settlements with the permission of the Settlement Commandant, ${ }^{4}$ was the legal basis of Uganda's refugee policy. The CARA has long been criticized for being antiquated and not reflective of the rights afforded to refugees in international law. ${ }^{5}$ In attempting to dispel this criticism, the Department of Disaster Preparedness and Refugees in the Office of the Prime Minister (OPM/DDPR) has been contradictory in its responses. OPM has argued that refugee protection and assistance in Uganda is in practice governed by international law, and that the policy which requires refugees to reside in settlements is in fact to the advantage of refugees themselves and in the interest of Uganda's national security. On the other hand, OPM ac- knowledged that the CARA, with its emphasis on refugee control, was restrictive in its approach to assistance and protection $^{6}$ and therefore that a new law should be enacted to address such shortcomings. ${ }^{7}$

Thus, prior to the new Refugee Act, which was assented to by the President of Uganda on 24 May 2006, the CARA was the legal basis for refugee settlements and the law governing refugees' protection and assistance. The new Refugee Act, hailed as a progressive document throughout Africa as it defers to several international human rights and refugee laws, retains the settlement policy. ${ }^{8}$ In practice, therefore, what exists today - and for the foreseeable future - is a policy that focuses assistance and protection on refugees living in settlements, and not those refugees who chose, for various reasons, to live outside such restrictive spaces. ${ }^{9}$ As has been demonstrated in previous studies, ${ }^{10}$ however, refugee settlements and camps are not conducive to conditions which enable refugees to fully enhance their capabilities to be independent, an intended goal of Uganda's settlement policy.

The current focus of Uganda's refugee policy therefore ignores the unknown number of refugees who live outside settlements, especially those in urban areas such as Kampala. Although the United Nations High Commissioner for Refugees (UNHCR) was in the process of ascertaining the number and identities ${ }^{11}$ of urban refugees in Uganda, as of April 2005, it had acquiesced to OPM's settlement policy and officially recognized only 210 individuals on its urban refugee caseload, out of an estimated number of between 10,000 and 50,000 which it established itself. ${ }^{12}$

Moreover, OPM and UNHCR's understanding of urban refugees appears to be limited to refugees in Kampala, to the exclusion of those in other urban centres, for instance, Mbarara, Kyenjojo, and Arua town centres. ${ }^{13}$ This raises questions regarding the definition of "urban refugees" employed by both OPM and UNHCR and highlights the lack of a coherent and cohesive urban refugee policy. Refugees in Kampala are only recognized if they have been referred from settlements to obtain medical assistance, to await resettlement, or on account of other protection or security concerns. This small group cited above therefore represents a minute fraction of refugees who have been referred from settlements. ${ }^{14}$ By focusing assistance and protection on refugees who live in settlements, current refugee policy in Uganda undermines refugees' freedom of movement and the right to choose their place of residence, as stipulated by Article 26 of the 1951 UN Convention relating to the Status of Refugees (hereinafter referred to as the Refugee Convention). In addition, it unnecessarily fragments refugees into many categories. 
Recently, OPM has begun to allow refugees to remain in Kampala and provide identity documents to them if they can prove "self-sufficiency." 15 By demanding evidence of employment and residency, ${ }^{16}$ OPM argues that this criterion for demonstrating self-sufficiency discourages those who cannot support themselves from remaining in the city. ${ }^{17}$ However, limiting the issuance of identity documents to those who can prove "self-sufficiency" though using such arbitrary criteria is discriminatory and violates the letter and spirit of the Refugee Convention: the Convention does not link refugee status to economic status.

In contrast to refugees living in settlements, who receive initial assistance in the process of becoming self-reliant, refugees in Kampala who are not listed on UNHCR's urban caseload do not receive any targeted assistance, except in cases of medical emergency. NGOs that provide assistance to refugees and asylum seekers in Kampala are, on the other hand, limited both by resource constraints and by the current policy framework which requires them to toe the government line, and thus the assistance provided is minimal at best. As a result NGOs are unable to meet the high demand for assistance in urban centres. Refugees who opt to remain in Kampala are therefore left to access the same services as ordinary residents. In some areas, such as access to health care, the problems refugees experience in accessing quality services are however no different than those experienced by Ugandans. Nonetheless, in the education and employment sectors, refugees suffer from discrimination and experience additional obstacles in accessing services beyond the difficulties faced by Ugandan nationals. As a result, refugees are left with few avenues for improving their socio-economic situation.

The following paper is organized in four distinct but interrelated sections. In Section 2, the paper explains why and how refugees come to Kampala. Section 3 describes refugees' immediate coping mechanisms upon arrival. This is followed by an analysis of the RSD process in Section 4, while Section 5 considers how refugees sustain themselves in Kampala, including how they access employment, health care, education, and other services. Finally, Section 6 examines protection issues faced by refugees in Kampala. The paper concludes that the overall policy on refugees in Uganda should support refugees' decisions to remain in Kampala rather than aiming to relocate urban refugees to rural settlements.

\subsection{Context}

The origins of this research relate to the many refugees and asylum seekers approaching the RLP's legal aid clinic for socio-economic assistance. As legal officers at the RLP found themselves listening to problems related to urban refugees' inability to meet their basic needs, the RLP began to question the effectiveness of the systems which are supposed to assist and support refugees in Kampala. These concerns pointed to a need for a study aimed at better understanding refugees' coping mechanisms - a study that would also gauge the thoughts and viewpoints of urban refugees themselves regarding the types of challenges they face. Urban refugees are under-researched generally - a quantitative demographic study of all urban refugees in Kampala is urgently needed to provide accurate statistics on the number of refugees living in the city as well as their needs.

Kampala is a city of roughly 1.2 million people $e^{18}$ and is comprised of five divisions. ${ }^{19}$ The city's population continues to grow at an annual rate of 4.5 per cent. ${ }^{20}$ Most of this growth, approximately 69 per cent, is due to rural-urban migration. ${ }^{21}$ Kampala City Council (KCC) states that the urbanization has been accompanied by an alarming increase in poverty levels ${ }^{22}$ and an immense strain upon available services. As noted in the KCC Development Plan, "The rate at which the city is developing is more than the capacity for the Kampala City Council to adequately plan and implement plans." 23

At the same time, in urban centres throughout sub-Saharan Africa, refugee populations are growing. ${ }^{24}$ Despite this increase, UNHCR's 1997 policy on urban refugees states, "as a rule, UNHCR's assistance should be reduced to a minimum." 25 While, of course, assistance in all settings should focus on refugees' attaining self-reliance, UNHCR's global policies need to take into account that "a significant and long-term investment may be required to promote self-reliance in an effective manner." 26

\subsection{Methodology}

This study is based on 160 interviews with refugees, asylum seekers, city officials, UNHCR and OPM representatives, and NGOs that work with refugees. The study was conducted from mid-September 2004 to January 2005. ${ }^{27}$

Qualitative interviews and participant observation were the main methods used in conducting this study. Due to time and capacity constraints, the study provides a limited understanding of the entire urban refugee population but raises several issues which affect most urban refugees and thus warrants response from appropriate stakeholders.

Throughout this study, efforts were made to take into account the views and concerns of interviewees. For instance, after speaking informally with Rwandese refugees at the RLP, these refugees made known that due to security concerns, they felt extremely uncomfortable with the prospect of researchers visiting their homes and conducting interviews in their neighbourhoods. In response, interviews 
with Rwandese refugees were conducted in a setting where they felt comfortable and safe.

The study also relied upon participant observation. For example, at the start of the study researchers introduced themselves to "ASSOREF," a francophone refugee association, and "FASSOREF," a women's francophone refugee association, and attended a number of their meetings in an observational capacity. Members of these groups also provided helpful information as to where in Kampala other refugees could be located.

Research was carried out in most locations in Kampala where refugees reside. ${ }^{28} \mathrm{~A}$ number of respondents were accessed with the help of organizations working with refugees, which provided information about areas of residence and additional contacts. Upon arrival of researchers in each area, introductions were made to local councillors and refugee leaders, who initially watched closely who was interviewed and where interviews were conducted. However, our prolonged presence in each area eventually allowed a greater degree of flexibility, and thus it is hoped that a broad spectrum of responses was gathered. The different language skills of the researchers, including English, French, and Kiswahili, were also an asset in gaining a variety of opinions. On a few occasions, interpreters were used in the course of research. Interpreters were either staff members of other organizations who work with refugees and volunteered their time, or individuals recommended to the RLP by related organizations who were given a small stipend.

One shortcoming of this study is that although local leaders and elected officials were interviewed in areas where refugees reside, no interviews were conducted with Ugandan community members due to time and capacity constraints. The experiences and perspectives of host communities would have helped to provide an understanding of their socio-economic situation in relation to refugees. This, in turn, would provide a basis for formulating a holistic policy aimed at improving the situation of refugees and the Ugandan urban poor alike.

Two other empirical issues need highlighting. First, the original intention was to compare findings from interviews of refugees on the urban caseload with those refugees who are not on the urban caseload and thus do not receive any formal assistance. This strategy proved impossible as it was difficult to determine with any degree of certainty who was on the urban caseload and who was not. It may be that refugees are hesitant to reveal that they are on the urban caseload, because they fear possible repercussions if they acknowledge support from multiple sources. In addition, the urban caseload fluctuates due to some refugees being resettled to third countries and other refugees being re- turned to refugee settlements after medical treatment has been completed in Kampala.

Second, although it was clarified at the outset of every interview that the researchers were not involved in provision of assistance and protection, many refugees insisted on showing us their documents, assuming that an interview would improve their chances of resettlement. Often researchers found themselves explaining how the refugee registration process functioned. These experiences directly relate to our research findings: many refugees stated that they lacked direct access to government and UNHCR officials, and many were also confused about the registration process.

\section{Methods of Arrival in Kampala}

Officially, when asylum seekers arrive in Uganda, they are expected to report to the nearest police post at the point of entry. ${ }^{29}$ However, in practice many asylum seekers travel directly to Kampala for a number of structural and bureaucratic reasons. First, asylum seekers reported lack of information regarding registration procedures at border entry points and therefore believed that they had to travel to Kampala to officially register as refugees. Second, asylum seekers who fled their country in large numbers often made no explicit decision about where to register and headed for Kampala as soon as crossing into Uganda. ${ }^{30}$ A number of refugees from the eastern Democratic Republic of Congo (DRC) stated that their method of flight precluded registration in border areas as they entered Uganda riding on lorries transporting goods headed directly for Kampala. ${ }^{31}$ Refugees and asylum seekers were also acutely aware of security issues and felt that remaining in a border area would continue to jeopardize their physical safety. ${ }^{32}$

In addition, numerous refugees move to Kampala after first residing in refugee settlements for reasons relating both to physical safety and access to employment and services. For instance, refugees in Pader, Yumbe, and Arua districts have been attacked in the past by rebels operating in northern Uganda and the West Nile region, forcing many to flee from settlements to other areas of the country, including Kampala, citing threats to their physical security. ${ }^{33}$ Many of these refugees never "decided" to leave the settlements; rather, they fled in the midst of chaos resulting from an armed attack. ${ }^{34}$

Such threats to refugees' security do not only emanate from external sources. The alleged presence of Congolese and Rwandese rebel groups in settlements also motivated refugees to move to Kampala. ${ }^{35}$ For example, a Congolese refugee stated that he "would never return to the camps ... there is too much insecurity ... Rwandese agents are there." 36 Another Rwandese refugee stated that he 
“wouldn't return to Nakivale [refugee settlement] because of safety issues." 37

Other refugees stated that they had left settlements due to harsh social and economic conditions. ${ }^{38}$ In addition, a number of refugees also stated they had left their settlements in order to access certain services or to take advantage of commercial markets - they planned to return to their respective settlements upon completion of their task outside the settlement. This mobility suggests that some refugees may be benefiting from services that are offered in settlements while simultaneously exploiting their creative abilities in a major commercial centre such as Kampala. ${ }^{39}$ For instance, while one refugee leader said, "No one can say that they like life in the camp. I have been [there] and know what they are like. If you tell them [refugees] to go to the camp, they will not go." 40 Another respondent stated, "I would never return to a camp because of a job in Kampala." ${ }^{41}$ Yet, still other refugees had left their settlements in order to access certain services or to take advantage of commercial markets but planned to return to their respective settlements upon completing their mission. ${ }^{42}$

\section{Assistance and Support Available to Asylum Seekers upon Arrival}

\subsection{Access to Shelter, Medical Care, and Food upon Arrival}

Upon arrival in Kampala, the majority of asylum seekers face immense difficulties accessing basic services such as health care, shelter, and food. Some asylum seekers already have friends or relatives in Kampala who may provide initial support. Many refugees and asylum seekers interviewed, however, appeared to be without such networks and therefore have few options for accessing basic services. Refugees from two different nationalities revealed that they randomly inquire in bus stations and on the street where they might find other people of the same nationality upon arriving in Kampala. ${ }^{43}$

The only two organizations that specifically assist asylum seekers in Kampala, InterAid and the Jesuit Refugee Services (JRS) are both overstretched and readily admit to the lack of capacity to assist and provide for all asylum seekers. ${ }^{44}$ Moreover, not only are these organizations UNHCR's Implementing Partners (IPs) who are, therefore, not free from bureaucratic dysfunctions obtaining from contractual obligations, they are also influenced by government policy which requires assistance for refugees to be provided in settlements. In other words, the assistance offered in Kampala terminates once refugee status has been accorded, and in some cases even before, depending on the availability of resources. The limited extent to which assistance is pro- vided is specifically intended to encourage refugees to go to settlements as soon as they have been given refugee status.

\subsection{Methods of Survival upon Arrival}

Due to the considerable gap between the demand for assistance and the amount of assistance that is actually available, many asylum seekers sleep out on the streets and in other public places, outside Kampala Police Station, the RLP, or InterAid. ${ }^{45}$ One refugee stated that he used to sleep outside Old Kampala Police Station but was told that if he continued to sleep there he would be taken to Luzira prison. ${ }^{46}$ Even when assistance is made available (usually by JRS and InterAid), the amount is so small that it may not be enough to rent a room, and therefore refugees have to resort to "good Samaritans," characteristically religious people some of whom are refugees themselves, for assistance. ${ }^{47}$ While it is positive that individuals are willing to extend personal support to asylum seekers and refugees, once assistance is provided in the personal realm, its continuity and dependability are no longer guaranteed, and this may engender avenues for exploitation of vulnerable refugees and, in the absence of external monitoring, promote neglect and abuse. For example, a female Burundian refugee who had found support from a Congolese man stated, "The main problem is staying in someone's house and depending on [this] man for food ... he may get tired of us and send us away." 48

When issues related to physical safety and security arise for refugees in Kampala, access to social support and other protective mechanisms is limited because of the GoU's policy of focusing refugee assistance and protection in rural settlements, ${ }^{49}$ and the growing perception among the local population that refugees contribute to increasing levels of crime. However, since the community in Kampala "is not sensitised to what a refugee is," 50 and because police records do not disaggregate foreign criminals by their legal status in the country, it is impossible to attribute these crimes specifically to refugees. It comes as no surprise, therefore, that refugees have become scapegoats for general problems affecting the wider community.

Often, the only solution offered to refugees who experience protection issues in Kampala is relocation to settlements, and as a result many refugees find themselves facing an impossible dilemma. On the one hand refugees have grave protection concerns and at the same time compelling reasons to remain in Kampala. On the other hand, settlements provide the promise of protection but no real guarantees and indeed limited avenues for utilizing their skills so as to support themselves. This implies that refugees in Uganda are often in a Catch 22, having to choose between a rock and a hard place. In light of this, GoU/UNHCR policy, which requires refugees to live in settlements, inad- 
vertently convolutes the process of assistance and protection of refugees, challenging the refugee status determination process (RSD) by making protection, the main objective of the RSD process, dependent on geographic location, and thus undermining the conventionally agreed definition of refugees.

\section{The Refugee Status Determination}

\subsection{The Official Process}

This section highlights some persistent problems in the Refugee Status Determination (RSD) process and the limited extent to which issues raised previously by the RLP have been addressed by OPM and UNHCR. In July 2002, the RLP published a report on the RSD process which described a largely unstructured RSD process, with multiple processes built into one supposedly "standard" process. ${ }^{51}$ In addition, previous research found that the GoU had different RSD procedures for different nationality groups. ${ }^{52}$ The current study found that to a limited extent, RSD procedures have been standardized and the practice of officially employing different procedures for different nationalities ended, yet refugees still do not understand the different responsibilities of UNHCR and the GoU in the RSD process; neither do they have full comprehension of the specific role of UNHCR's implementing partners. Some of the problems earlier identified therefore still exist. ${ }^{53}$ In addition, because of the requirement that refugees live in settlements, ${ }^{54}$ provision of humanitarian assistance to urban refugees is inextricably linked to the RSD process. ${ }^{55}$ In most cases, when asylum seekers are granted refugee status in Kampala, all assistance and support is terminated as a means to encourage movement to settlements.

\subsection{Step Two: Permission to Remain in Kampala}

Once refugee status is granted, UNHCR writes an acknowledgment letter that states to which settlement the refugee is being referred. OPM endorses such letters and then, through InterAid, refugees are sent to the appropriate settlement. ${ }^{56}$ Refugees who wish to remain in Kampala begin a second process, in the course of which they have to demonstrate why they should remain in the urban centres. This second process impacts on the refugees' status by undermining the potency of the initial process of RSD. Those who remain in Kampala but are not on the UNHCR/OPM urban caseload become virtually invisible to refugee protection mechanisms in Uganda. In essence, the GoU/UNHCR policy of leaving refugees who wish to remain in Kampala to fend for themselves has in a way made some refugees more refugees than others. Similarly, provision of assistance only in camps ensures rigid distinction between protection and assistance and undermines the protective nature of assistance.
As noted above, refugees are now allowed to remain in Kampala if they are able to prove "self-sufficiency," in the form of either proof of residency or proof of employment. ${ }^{57}$ OPM has stated that it does not wish to encourage "desperate" refugees to remain in Kampala, and wants to limit permission to reside in Kampala to professionals, students, and others who have viable means to support themselves. ${ }^{58}$ Self-sufficiency is, however, a fluid state that can easily slip away due to a number of circumstances - including loss of jobs, family illness, and fluctuating incomes - and therefore not necessarily a sound basis for deciding where and how to protect refugees. Moreover, this policy has only been verbally articulated by both OPM officials and refugees and has been extremely difficult to monitor. ${ }^{59}$

Regardless of the way the policy is implemented in practice, the policy creates a link between refugee status and "self-sufficiency" which undermines the meaning of "refugee" as defined in international refugee law. ${ }^{60}$ For those refugees who wish to stay in Kampala, the policy makes the issuing of identity documents dependent on refugees' being able to prove self-sufficiency. In these circumstances, the inevitable result of the policy is that even if refugee status has been granted, the identity document which acts as tangible proof of refugee status may be withheld if the refugee in question wishes to remain in Kampala and is unable to prove being self-sufficient. This is contrary to Uganda's obligations under the Refugee Convention, according to which Uganda must accord to all refugees the right to choose their place of residency and to move freely within its territory (Article 26), and must issue identity papers to all refugees in its territory who do not possess valid travel documents (Article 27).

Finally, even for those refugees who manage to prove their "self-sufficiency" and who are given identity documents, the problems do not necessarily end. The only services that they can continue to access as refugees are emergency medical assistance offered to all refugees by InterAid, and InterAid's credit schemes. ${ }^{61}$ For all other services, they have to rely on Kampala's municipal services. As will be demonstrated in section 5 of this paper, however, local government officials and civil servants in Kampala do not appear to be aware of the presence of refugees in the city, and refugees are not budgeted for in city planning provisions.

\subsection{Flaws and Injustices in the RSD Process}

Although the RSD process is accessible to the majority of asylum seekers in Kampala, findings indicate a number of fundamental flaws in the process that must be addressed by UNHCR and OPM. 
First, asylum seekers are not allowed legal representation in the first instance. ${ }^{62}$ Second, asylum seekers who are denied refugee status by the Refugee Eligibility Committee (REC), the first decision-making body which reviews written appeals, are not provided with a legal reasoning as to why their claim was denied. ${ }^{63}$ As a result, appeals are drafted with limited understanding of the reasons why particular cases were denied in the first instance. Furthermore, an independent appeals process separate from the REC is nonexistent; asylum seekers may only request that their case be reviewed by the REC for a second time. ${ }^{64}$

While the new Refugee Act includes a provision for a Refugee Appeals Board to be established separately from the REC, ${ }^{65}$ this Appeals Board only has the power "to set aside the decision of the Eligibility Committee [the REC] and refer the matter back to the Committee for further consideration and decision." 66 In other words, the Board may offer an opinion on a case, but it is not granted the power to substitute its own decision for the REC's decision at first instance. An express provision for a right to appeal to a court of law does not yet exist in the new legislation.

In addition to the above, findings also demonstrate that refugees do not receive clear information about the RSD process, and as a result many of them question the integrity and impartiality of the process. Even if asylum seekers knew how the RSD process worked, a number reported being denied access to the process. In particular, the lack of direct access to those who make refugee status decisions caused anger and confusion amongst refugees and asylum seekers.

A number of female refugees and asylum seekers reported sexual harassment at different stages of the RSD process. While none of these claims could be independently verified, and recognizing the power of rumours, the fact that the above complaints exist are worrying and show the need for careful monitoring of the RSD process by both OPM and UNHCR. Mechanisms and procedures for filing formal complaints regarding any misconduct on the part of interviewers should also be instituted and information about such procedures should be made available to all refugees and asylum seekers, especially females.

The situation of accompanied minors and how they proceed through the RSD process is also in need of careful monitoring. How the "self-sufficiency principle" is applied to accompanied minors is of particular concern and requires further investigation. ${ }^{67}$

\section{Refugees in Kampala: Livelihoods and Sustainability}

Once asylum seekers are given refugee status, assistance and support is limited to those on the urban caseload, and as noted above, this group represents an exceedingly small fraction of the entire urban refugee population. Many refugees, therefore, reported difficulties in accessing city services for two principal reasons. First, many Ugandan service providers associate the term "refugee" with "UN" or "NGO"68 and therefore assume that refugees are not only well provided for, they are in fact better off than Ugandan nationals since they are under the care of UNHCR. ${ }^{69}$ Second, it is assumed by Kampala's elected leaders and service providers that all refugees live in settlements. ${ }^{70}$ Both of these assumptions are false, as UNHCR provides marginal assistance to refugees and this support is only provided in settlements. Generally, the lack of information on refugee issues on the part of Kampala city officials was found to be extremely poor. For example, one KCC official noted that "real refugees... are unable to support themselves [and] got to camps." 71 The Chief Town Planner of Kampala stated that although he believed there were refugees in Kampala, neither he nor his department had recorded them, and he thought they were looked after by the Ministry of Internal Affairs. ${ }^{72}$ Indeed, refugees are not budgeted for in city development plans and thus the municipality has no means to assist them. This situation evidences the need for those mandated to protect refugees in Uganda, i.e. OPM and UNHCR, to inform and sensitize city officials on refugees in Kampala, their needs, and how they can be best sustained and supported.

Due to the "self-sufficiency principle," refugees who opt to live in Kampala when they are not on the urban caseload are in fact unable to access any material support from UNHCR, JRS, or InterAid. And as a result of service providers' mistaken perception noted above, services may be denied to refugees, or refugees may be charged for what are usually free services. Language barriers also impede the ability of refugees to utilize city services.

For example, in regard to access to education, the Ugandan Constitution explicitly states that "all persons have the right to education."73 The Refugee Convention also requires Contracting States to "accord to refugees the same treatment as is accorded to nationals with respect to elementary education." 74 The 1989 Convention on the Rights of the Child (CRC), to which Uganda is a party, affords the right to education and also includes a non-discrimination clause, from which it follows that the right to education cannot be denied to refugee children. ${ }^{75}$

Although in 1997, Universal Primary Education (UPE) was introduced in Uganda, exempting four children per family from paying primary school fees, research findings indicate that most urban refugee families are unable to meet the cost of education for their children and - since this education is not entirely free ${ }^{76}-$ as a result, many refugee children in Kampala are unable to access education. In- 
terAid does provide limited education bursaries to refugee families, but only to families who are on the urban caseload. ${ }^{77}$ As educational implementing partner to UNHCR, Windle Trust also provides a number of scholarships to refugee children, yet only to students in refugee settlements holding ration cards. Thus urban refugee children are not considered for scholarships, despite the fact that Windle Trust reports that not only does it receive weekly requests from refugees in need of educational assistance in Kampala, but also that the Trust cannot fill all of its scholarship quotas in settlements due to a lack of qualified applicants. Moreover, according to Windle Trust, there are many refugee children in Kampala who may meet the requirements for scholarships to be awarded. ${ }^{78}$ There is no legal basis for this discriminatory way of allocating scholarships. In this case, providing benefits which should be available to all refugees in Uganda but are only available to those in settlements further substantiates how refugees are enticed to move to settlements and is a very tangible example of how refugees in Kampala are denied the ability to exercise their rights afforded to them in the Refugee Convention.

These problems are replicated in other service sectors: for example, access to employment, credit, and other business opportunities, shelter, and social integration. With respect to the last, refugees experience difficulties integrating into the Ugandan community, mainly due to languagerelated communication problems ${ }^{79}$ a diverse cultural mosaic in Uganda which engenders "different mentalities" 80 between refugees and their Ugandan hosts, and xenophobic statements relating to refugee presences in Kampala. Hence a local leader reported complaints made against the Somali community in regards to their cleanliness. ${ }^{81}$

While these portrayals are largely negative, research also revealed that in some areas of service provision, such as health care, refugees do not report any discrimination and are able to access services like any Ugandan resident of Kampala.

\section{Protection and Security: The Need for a Broader Protection Strategy}

Ensuring economic sustainability is only one aspect of protection for refugees in Kampala. When asked about their main problems, many refugees reported concerns relating to their physical security and the difficulties they experienced in seeking redress when a crime had been committed against them. Endemic corruption within the Ugandan police system not only affects ordinary residents; refugees also have to reckon with the additional problems of negotiating their legal status as well as having justice secured on their behalf, opening further ground for exploitation. While it may be argued that Ugandans also experience crime ${ }^{82}$ and difficulties with the police, ${ }^{83}$ refugees face specific obstacles in seeking redress for crimes committed against them. Many refugees stated that they were wary of reporting criminal incidents to the police because of fears of Uganda's alleged relationships with rebel groups in their countries of origin. As a result of this situation, a number of refugees stated they preferred to solve disputes and problems amongst themselves. ${ }^{84}$ The resort to extra-legal avenues to solving disputes often leads to further violations of rights and does not bode well for the image of refugees.

The genuine concerns regarding physical security after refugee status has been granted evidence the need for the GoU and UNHCR to be actively involved in securing refugees' safety and protection at all times, and in all locations within Uganda and especially Kampala where most refugees lack access to protection mechanisms and social support networks. It should also be emphasized that in addition to concerns regarding physical security, the difficulties experienced by urban refugees in accessing Kampala's municipal services have a direct impact on their human security.

In this respect, it is instructive to recall the definition of protection put forward by the International Committee of the Red Cross, which defines protection as "encompassing all activities aimed at obtaining full respect for the rights of the individual in accordance with the letter and the spirit of the relevant bodies of law (i.e. HR law, IHL, refugee law)." 85 Notice should also be taken of the words of UNHCR's Senior Protection Officer in Kampala, who stated: "In the developing world, assistance is protection. If you don't feed them [refugees], they die. There is no clear division." 86 Thus a GoU and UNHCR protection strategy should ensure access to fair RSD procedures and guarantee the observance of the principle of non-refoulement, and also should ensure that refugee protection in the widest sense is extended not only to refugees residing in settlements but also to the urban refugee population.

\section{Conclusion}

For some refugees, an urban setting offers the most conducive environment for achieving self-sufficiency. This paper asserts that decisions by refugees to remain in urban environments should be supported rather than undermined.

Research findings indicate that at all stages of their being in exile in Uganda, refugees are put under pressure, either implicitly or explicitly, to relocate to settlements. This overreliance on settlements as the only model for refugee protection and assistance has hampered progressive thinking 
and the involvement of other Kampala-based welfare organizations in providing assistance to refugees in Kampala.

Refugees choosing to remain in Kampala are only officially allowed to do so when they can prove themselves to be self-sufficient. Whether or not they can prove self-sufficiency to the satisfaction of OPM, refugees should be allowed to remain in Kampala if they wish to do so. Furthermore, the issue of self-sufficiency should not determine whether a refugee receives a refugee identity document.

When asylum seekers arrive in Kampala, the assistance they receive is minimal. Once refugee status is granted, for the majority of refugees assistance stops altogether. The study found that the majority of urban refugees live in poverty and lack the means to improve their socio-economic situation. While many Ugandan nationals face the same problems as the urban refugees in Kampala, refugees are especially disadvantaged for a variety of reasons, including lack of legal status, language barriers, and discrimination in respect of their attempts to access education and employment.

Part of the difficulty refugees have in accessing services in Kampala arises out of the fact that those who provide services are generally unaware of the presence of refugees in Kampala and are confused about the rights of the urban refugee population. As assistance to refugees is focused on refugees residing in settlements, city officials assume that all refugees reside in settlements. There is a direct correlation between the limited knowledge of city officials regarding the presence of refugees in Kampala and the ability of urban refugees to meet their needs. There is therefore a clear need for city officials and service providers in Kampala to be made aware of the presence of urban refugees in Kampala and of the rights accorded to refugees under national and international law.

Despite the difficulties faced by the urban refugees in Kampala, many of them choose to remain in Kampala instead of moving to one of the refugee settlements. These decisions are driven by a variety of reasons, of which perhaps the most important is that refugees judge Kampala to be the most conducive environment for attaining a state of self-reliance. This paper asserts that the choices of refugees relating to the environment in which they choose to live should be supported rather than undermined.

\section{Notes}

1. Within the government, there is a general lack of progressive and coherent thought on the implications of the presence of refugees in Uganda. This is reflected in the "continued movement of the department of refugees from one Ministry to the other." Ronald Kalyango, "Non governmental organisations and the Provision of Humanitarian Assistance to Urban Refugees in Kampala" (MA diss., Makerere University, 1999), 14 (on file with the RLP).

2. Note that the RLP has previously documented the RSD process in Kampala. See, for instance, Kirk Huff and Ronald Kalyango, "Refugees in the City: Status Determination, Resettlement, and the Changing Nature of Forced Migration in Uganda" (Working Paper No. 6, RLP, July 2002). For further information also see Barbara Harrell-Bond and Guglielmo Verdirame, Rights in Exile: Janus-Faced Humanitarianism (Oxford: Berghan Books, 2005).

3. The Control of Alien Refugees Act, 1960, Laws of Uganda, Cap. 64.

4. Section 8 of the CARA requires all refugees to reside in settlements.

5. See for example, Guglielmo Verdirame, "Human Rights and Refugees: The Case of Kenya," Journal of Refugee Studies 12 (1999): 54; Harrell-Bond and Verdirame, 2005.

6. OPM Senior Protection Officer, OPM, Directorate of Refugees, interview by the RLP, Kampala, October 3, 2004.

7. While the draft version of a new refugee act grants refugees the right to freedom of movement, the act also gives the Commissioner discretion to limit freedom of movement (Section 30).

8. See the Refugees Bill 2003, s. 44, Bills Supplement No. 8, Uganda Gazette No. 58 XCVI, November 21, 2003.

9. As one example, the conditions in refugee settlements in the West Nile region of Uganda have most recently been documented and analyzed in Tania Kaiser, Lucy Hovil, and Zachary Lomo, "'We are all stranded here together': The Local Settlement System, Freedom of Movement, and Livelihood Opportunities in Arua and Moyo Districts" (Working Paper No. 14, RLP, February 2005).

10. As examples, see Richard Black, "Putting Refugees in Camps," Forced Migration Review 2 (1998); Jeff Crisp and Karen Jacobson, "Refugee Camps Reconsidered," Forced Migration Review 3 (1998); Barbara Harrell-Bond, "Are Refugee Camps Good for Children?” (Working Paper No. 29, New Issues in Refugee Research, 2000); Wim van Damme, "Do Refugees Belong in Camps? Experiences from Goma and Guinea," The Lancet 346, no. 8971 (1995): 360-362. The United States Committee for Refugees and Immigrants (USCRI) is currently campaigning for an end to the practice of forcing refugees to live in camps and settlements; see $<$ http://www.refugees.org $>$.

11. UNHCR Country Operations Plan, Overview: Uganda, Planning Year 2006.

12. United Nations Office for the Coordination of Humanitarian Affairs (OCHA), Humanitarian Update Uganda 7, no. 4, Kampala, Uganda, April 2005.

13. UNHCR Protection Officer, telephone conversation with the RLP, Kyenjojo, May 11, 2006.

14. Director, InterAid Uganda, interview by the RLP, Kampala, October 6, 2004.

15. OPM Senior Protection Officer, OPM, Directorate of Refugees, interview by the RLP, Kampala, October 3, 2004.

16. Ibid. 
17. Ibid.

18. “District Development Plan: 2004/2005 - 2006/2007," Planning Unit, Kampala City Council, at 130 (on file with the RLP).

19. The divisions are: Lubaga, Makindye, Nakawa, Central, and Kawempe.

20. Planning Unit, Kampala City Council, 129.

21. Ibid.

22. Ibid.

23. Throughout the global south, the number of urban refugees has "increased considerably." Ibid., 130.

24. Naoko Obi and Jeff Crisp, UNHCR Policy on Refugees in Urban Areas; Report of a UNHCR/NGO Workshop, UNHCR Evaluation and Policy Unit, Geneva (EPAU/2002/09), 2002, 1. There is a growing literature on urban refugees. See, for example, Loren Landau, "Study Guide to Urban Refugees," Forced Migration Online (February 2004), <www.forcedmigration.org/guides/fmo024> (accessed July 4, 2006); see also Gaim Kibreab, "Eritrean and Ethiopian Urban Refugees in Khartoum: What the Eye Refuses to See," African Studies Review 39, no. 3 (December 1996): 132.

25. United Nations High Commissioner for Refugees, UNHCR Policy on Refugees in Urban Areas (Geneva: UNHCR, 1997).

26. Obi and Crisp, 6. UNHCR is currently working on a revised policy on urban refugees.

27. Specifically, interviewees included 9 elected local government officials; 12 civil servants; 11 representatives from international organizations and non-governmental organizations; 5 refugee leaders; and 117 refugees, asylum seekers, and forced migrants. Finally, six focus group discussions with refugees were conducted.

28. Research was carried out in the following areas of Kampala: Bakuli, Kasubi, Kilombe, Kisenyi II, Lubaga, Makindye, Mengo, Mengo Kinsenyi, Mulago, Muyenga, Najjanankumbi, Nakulabye, Namirembe, Nsambya, Nsambya Kevina, Old Kampala, and Owino.

29. Divisional Special Branch Officer, interview by the RLP, Old Kampala Police Station, Kampala, October 5, 2004.

30. Refugee, interview by the RLP, Mengo, Kampala, September 28, 2004.

31. Refugee, interview by the RLP, Mengo Kisenyi, Kampala, September 29, 2004.

32. Refugee, interview by the RLP, Mengo, Kampala, September 27, 2004.

33. For more information on the conflict in West Nile, see Zachary Lomo and Lucy Hovil, "Negotiating Peace: Resolution of Conflicts in Uganda's West Nile Region" (Working Paper No. 12, RLP, June 2004).

34. This observation was also made by Kaiser, Hovil, and Lomo (Working Paper No. 14, RLP, February 2005).

35. Refugee, interview by the RLP, Mengo, Kampala, September 27,2004 . This complaint is also commonly heard in the RLP's legal aid clinic and usually relates to settlements, such as Kyaka II and Nakivale, that house Rwandese and Congolese refugees.

36. Refugee, interview by the RLP, Mengo, Kampala, September 27, 2004.
37. Refugee, interview by the RLP, Old Kampala, Kampala, October 6, 2004.

38. Refugee, interview by the RLP, Mengo, Kampala, September 27, 2004. See also, for example, Lucy Hovil, "Free to Stay, Free to Go? Movement, Seclusion and Integration of Refugees in Moyo District" (Working Paper No. 4, RLP, May 2002); Eric Werker, "Refugees in Kyangwali Settlement: Constraints on Economic Freedom" (Working Paper No. 7, RLP, November 2002).

39. Previous research conducted by the RLP resulted in similar findings: See Kaiser, Hovil, and Lomo, 2005.

40. Refugee leader, interview by the RLP, Lubaga, Kampala, October 11, 2004.

41. Refugee, interview by the RLP, Mengo, Kampala, September 29, 2004.

42. Refugee, interview by the RLP, Lubaga, Kampala, October 11, 2004; Refugees, focus group discussion with the RLP, Lubaga, Kampala, October 12, 2004.

43. Refugee, interview by the RLP, Mengo Kisenyi, Kampala, September 27, 2004. Other Somali refugees related similar experiences. Refugees, interviews by the RLP, Mengo Kisenyi, Kampala, September 28, 2004.

44. Director, InterAid Uganda, interview by the RLP, October 6, 2004; Project Director, Urban Programme, Jesuit Refugee Services, interview by the RLP, Kampala, October 4, 2004. For a more detailed account of assistance available to asylum seekers and refugee, in Kampala, see RLP, Working Paper No. 16, Section 3.1, May 2005.

45. The lack of shelter available to asylum seekers was also found to be an issue of concern in Huff and Kalyango, RLP Working Paper No. 6, July 2002.

46. Refugee, interview by the RLP, Lubaga, Kampala, October 11, 2004.

47. Refugee, interview by the RLP, Old Kampala, Kampala, October 6, 2004.

48. Refugee, interview by the RLP, Mengo Kisenyi, Kampala, September 28, 2004.

49. Section 6 of this paper analyzes protection and security issues in detail.

50. Kampala City Council Official, interview by the RLP, Kampala, October 12, 2004.

51. Huff and Kalyango.

52. Ibid., 11.

53. For a detailed description of the RSD process, please refer to RLP WP No. 16, Section 4, May 2005.

54. Ibid.

55. Ibid.

56. UNHCR Senior Protection Officer, UNHCR, Kampala, interview by the RLP, Kampala, October 8, 2004.

57. OPM Senior Protection Officer, OPM, Directorate of Refugees, interview by the RLP, Kampala, October 3, 2004. A letter from an employer is required to show proof of employment and a letter from a local councillor (LC) is required as means of proof of residency.

58. Ibid. 
59. Senior Legal Officer, RLP, interview by the RLP, Kampala, February 22, 2005.

60. International refugee law denotes treaty law, in particular the Refugee Convention and the 1969 OAU Convention; and soft law, including the Statute of UNHCR, ExCom Conclusions, United Nations General Assembly resolutions, and Security Council resolutions.

61. Director, InterAid Uganda, interview by the RLP, Kampala, 6 October 2004.

62. Huff and Kalyango.

63. Ibid.

64. Ibid.

65. The Refugees Bill 2003, s. 17, Bills Supplement No. 8, Uganda Gazette No. 58 XCVI, November 21, 2003.

66. Ibid., s. 17(2B).

67. For more information on the situation of accompanied minors in Kampala, see section 4.4., WP No. 16, RLP, May 2006.

68. Project Director, Urban Programme, Jesuit Refugee Services, interview by the RLP, Kampala, October 4, 2004.

69. Ibid.

70. Kampala Central Division Official, interview by the RLP, Central Division offices, Kampala, October 5, 2004.

71. Kampala Central Division Official, interview by the RLP, 5 October 2004.

72. Kampala City Council official, interview by the RLP, 4 October 2004.

73. Constitution of the Republic of Uganda, 1995, Article 30.

74. Refugee Convention, Article 22.

75. CRC, Article 28. Article 2 of the CRC states: "State parties shall respect and ensure the rights set forth in the present Convention to each child within their jurisdiction without discrimination of any kind, irrespective of the child's or his or her parent's or legal guardian's race, colour, sex, language, religion, political or other opinion, national, ethnic or social origin, property, disability, birth or other status."

76. UPE includes a number of "hidden costs." Research revealed that all parents must pay UgShs 10,400 per term per child at the primary level for their children to enrol in Kampala primary schools. Working Paper No. 16, 31.

77. Director, InterAid Uganda, interview by the RLP, Kampala, October 6, 2004.

78. Windle Trust, Programme Manager, Interview with RLP, 6 October 2004.

79. FASSOREF (Women's Association of Francophone Refugees), focus group discussion with the RLP, Old Kampala, Kampala, October 6, 2004; Refugee, interview by the RLP, Old Kampala, Kampala, October 6, 2004; Refugee, interview by the RLP, Mengo, Kampala, 27 September 2004; Refugee, interview by the RLP, Mengo, Kampala, September 29, 2004.

80. Refugee, interview by the RLP, Mengo, Kampala, September 29, 2004.

81. Kampala City Council Official, interview by the RLP, Kampala, October 5, 2004.
82. Kampala City Council's District Development Plan notes that crime in urban slums is a problem. Planning Unit, Kampala City Council, 131.

83. See Republic of Uganda, Report of the Judicial Commission of Inquiry into Corruption in the Uganda Police Force, May 2000 (on file with the RLP).

84. Refugee, interview by the RLP, Old Kampala, Kampala, October 6, 2004; Refugees, interview by the RLP, Mengo, Kampala, September 27, 2004.

85. International Committee of the Red Cross, "Background Paper,” Third Workshop on Protection, January 7, 1999. "HR law" refers to human rights law; "IHL" refers to international humanitarian law.

86. UNHCR Senior Protection Officer, UNHCR Kampala, interview by the RLP, Kampala, October 12, 2004.

Jesse Bernstein is currently a Country Analyst with the Norwegian Refugee Council's Internal Displacement Monitoring Centre (NRC/IDMC) and a former intern at the Refugee Law Project.

Moses Chrispus Okello is the Research and Advocacy Officer at the Refugee Law Project (RLP) and holder of an M.A. from the American University in Cairo.

This article has been adapted from RLP Working Paper No. 16 and can be accessed in its original form at $<w w w . r e-$ fugeelawproject.org $>$. The study was conducted as part of a larger research project funded by the MacArthur Foundation entitled "Questioning the Settlement Policy for Refugees in Uganda: A Socio-Legal Analysis." The views expressed in this article are solely those of the authors.

(C) Jesse Bernstein and Moses Chrispus Okello, 2007. This open-access work is licensed under a Creative Commons Attribution-NonCommercial 4.0 International License, which permits use, reproduction and distribution in any medium for non-commercial purposes, provided the original author(s) are credited and the original publication in Refuge: Canada's Journal on Refugees is cited. 